\title{
Physiological Analysis and Evaluation of Heavy Metal Contents in Leafy Vegetables and Fruits Collected from the Local Market of Prayagraj
}

\author{
Swati Singh Chandel ${ }^{1,}$, Amar Singh Rana ${ }^{1}$, Muhammad Ibrahim ${ }^{2}$ \\ ${ }^{1}$ Department of Environmental Sciences, Natural Resource Management, Sam Higginbottom University of Agriculture, Technology and \\ Sciences, Allahabad, Uttar Pradesh, India \\ ${ }^{2}$ Institute of Environmental and Agricultural Sciences, Faculty of Life Sciences, University of Okara, Renala Khurd, Pakistan \\ Email address: \\ swati.singh197@gmail.com (S. S. Chandel) \\ ${ }^{*}$ Corresponding author
}

\section{To cite this article:}

Swati Singh Chandel, Amar Singh Rana, Muhammad Ibrahim. Physiological Analysis and Evaluation of Heavy Metal Contents in Leafy Vegetables and Fruits Collected from the Local Market of Prayagraj. International Journal of Statistical Distributions and Applications. Vol. 7, No. 1, 2021, pp. 7-12. doi: 10.11648/j.jjsd.20210701.12

Received: December 28, 2020; Accepted: January 8, 2021; Published: March 10, 2021

\begin{abstract}
The following research work has been undertaken to examine the presence of heavy metals i.e lead $(\mathrm{Pb})$, Cadmium (Cd), Copper ( $\mathrm{Cu}$ ), Iron $(\mathrm{Fe})$, Cobalt $(\mathrm{Co})$ in some selected vegetables and fruits supplied in the local market. The process used to determine heavy metals is Atomic Absorption Spectrometer. Iron concentration in spinach, tomato, cauliflower and lady finger showed higher ranges which were exceeding the permissible limits. Cauliflower and spinach were within the limits specified. The $\mathrm{pH}$ value, ascorbic concentration and moisture content significantly decreased after oven drying of vegetables and fruits. However, the Total Soluble Solids (TSS) and ash content significantly increased after oven drying as compared with fresh vegetables and fruits. The present research data revealed that the fresh and oven dried vegetables such as Spinach, Cauliflower, Lady finger and Tomato contains $0.13-1.50 \%, 0.25-2.32 \%, 0.26-2.52 \%$ and $0.19-3.13 \%$ Titratable acidity respectively. Similarly, fresh and oven dried Guava Titratable acidity was highest 0.27 and 1.92 as compared with Water melon and Mango. The reduction in acidity may be due to catabolic activities in fruit cells and increased in $\mathrm{pH}$. The $\mathrm{pH}$ value of vegetables and fruits dropped after oven drying. Similarly, ascorbic concentration and moisture content significantly decreased after oven drying as compared to fresh vegetables and fruits. However, the Total Soluble solids (TSS) and ash content significantly increased after oven drying as compared with fresh vegetables and fruits. Overall from the following study we can conclude that vegetables and fruits were found to be contaminated by heavy toxic metals. Regular monitoring is required because these toxic metals will damage human body as well disturb our food chain. The main objective to conduct this study is to monitor the heavy metal toxicity and provide some recommendation, which in future will assure food safety and human health.
\end{abstract}

Keywords: Vegetables, Heavy Metals, Fruits, Human Health

\section{Introduction}

Vegetables and fruits are of great value and widely used for dietary purposes globally. Fruits are an important constituent because of vitamins, mineral salts, water, nutrients such as calcium (Ca), iron (Fe), Sulphur (S) and potassium [1]. They protect our body from foreign infections. Presence of heavy metals in food supplies will not only cause harm to our body but will also damage our food chain. Due to easy availability of wastewater and scarcity of freshwater, it is mostly used for irrigation of vegetables and fruits. Waste irrigation is thought to make a considerable contribution to presence of heavy metals in waste water. The metals content of the soil are dangerous because they do not get degrade easily and they can easily get assemble in our body. Inaddition these metals are dangerous because they can easily dissolve in our water bodies. A small amount of these metals is harmful because there is no proper method to remove these 
metals from our body. Heavy metals find their use in many industrial applications and so there are widely spread. Due to this reason the available wastewater have large unit of these heavy metals in them as which when indirectly used for irrigation severely effects human body [2]. Excess amount of accumulation in agricultural land irrigated by wastewater affects the food quality. The metal requirement in our body is obtained from the food and water that we consume and this in turn directly exposes us from the entry of toxic heavy metals [3].

Vegetables play an important role in our daily diet because it has vitamins, minerals dietary fiber and antioxidants. Leaves from different plant species such as perennial and annuals are consumed especially in rural areas and there has been an increased trend of the consumption among the persons living in metro cities. Vegetables which have leaves as edible part are an economic source to ensure the micronutrient intake. Examples include Spinach, Cauliflower, Ladyfinger, Tomato, Watermelon, Mango, Guava.

Rapid industrialization and the use of natural resources have increased the accumulation of toxic substances like heavy metals in the soil [4]. The required protein and vitamin which are supplied by vegetables are best to act against rough digestion and prevents constipation are supplied by vegetables. The current research work was conducted with a view to calculate the amount of heavy metals that enter in our body through the agricultural practices that involves the use of wastewater irrigation. The various disadvantage of using wastewater was noticed and daily intake of heavy metals was calculated with regard to different section of society.

\section{Materials and Methodology}

\subsection{Study Area}

The following study was conducted in Prayagraj (Figure 1) formerly known as (Allahabad) market which is located at $25.45^{\circ} \mathrm{N} 81.84^{\circ} \mathrm{E}$ in the southern part of the Uttar Pradesh, at an elevation of 98 meters, shown in figure 1 . It stands at the confluence of two rivers Ganges and Yamuna. It is one of the famous holy cities of India, well known for Magh Mela.

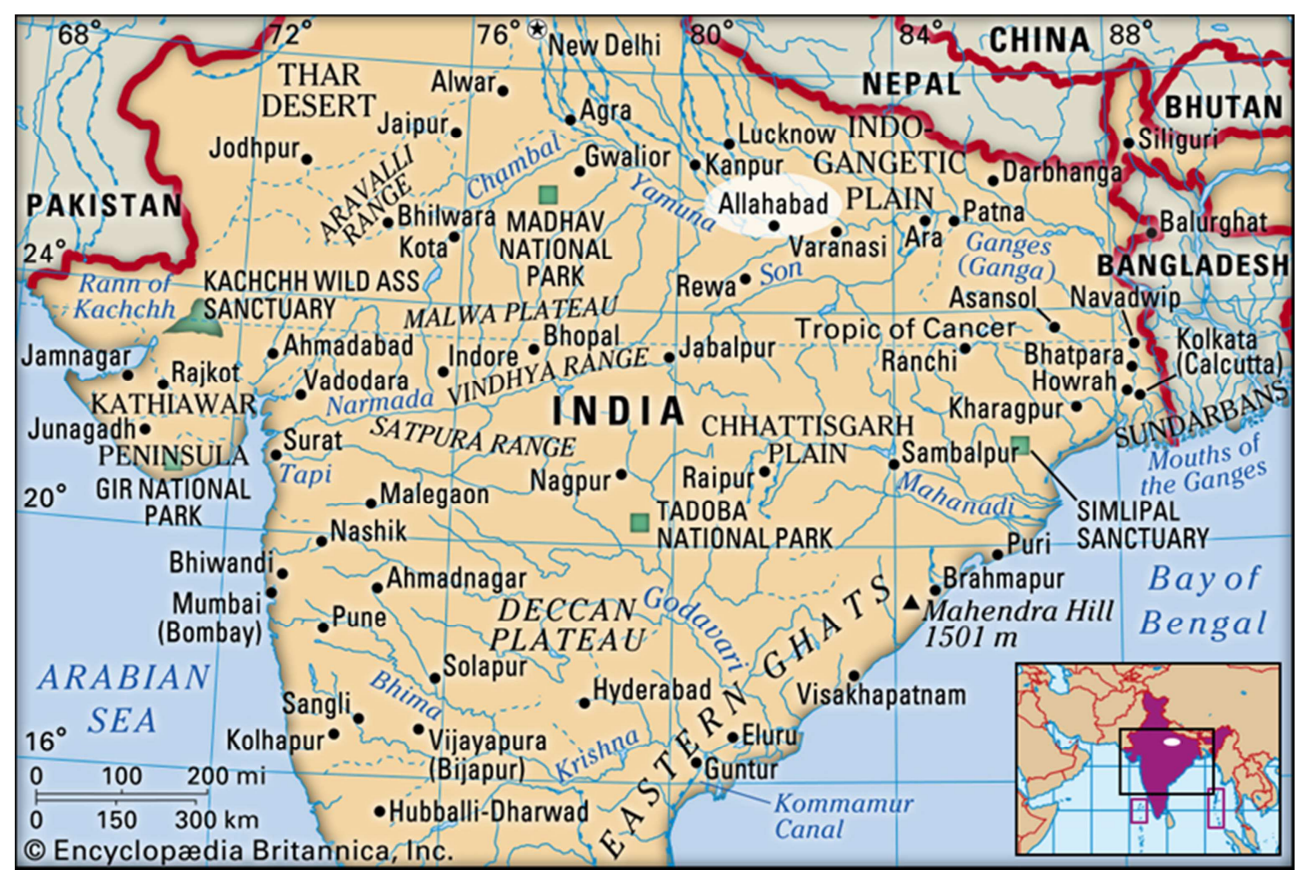

Figure 1. Site selected for sample collection.

\subsection{Samples Collection Site}

Table 1. Selected fruits and vegetables for the study.

\begin{tabular}{ll}
\hline Common name & Botanical names \\
\hline Selected vegetables & \\
Spinach & Spinacia oleracea. L. \\
Tomato & Solanum lycopersicum. L. \\
Cauliflower & Brassica oleracea. L. \\
Selected fruits & \\
Mango & Mangifera indica. L. \\
Watermelon & Citrullus Lanatus thumb \\
Guava & Psidium guajava. L \\
\hline
\end{tabular}

The selected fruits and vegetables for the following study (Table 1) were collected from transporter who were bringing these products from the farmers and were shifting them to local markets. We have taken the edible portions of the vegetables selected for the study.

\subsection{Determination of $\mathrm{pH}$}

$\mathrm{pH}$ of each figure sample was measured with the help of digital $\mathrm{pH}$ meter (AD 1020) by standard method described by AOAC (2006).

Total Soluble Solids (TSS): Total soluble solids were measured according to procedure of AOAC (2006) using 
digital refractometer at room temperature.

Moisture Content: Moisture content was measured by using the method prescribed by AOAC (2006).

Moisture $\%=\frac{\text { Weight of sample }- \text { weight of sample after drying }}{\text { Weight of sample }} \times 100$

Determination of Titratable Acidity: Total titratable acidity was measured by standard literature method given by AOAC (2006) by using $100 \mathrm{ml}$ volumetric flasks separately.

Determination of Ascorbic Acid

Ascorbic acid was determined with the help of standard method described in AOAC (2006).

Total Ash Content

Ash content was determined by using AOAC method (2000). Ash content was determined by applying following formula:

$$
\text { Percent Ash }=\frac{\mathrm{W} 3-\mathrm{W} 1}{\mathrm{~W} 2} \times 100
$$

\subsection{Preparation of Sample}

To remove harmful chemicals from the different vegetable samples double distilled water was used. Water content from the edible parts of the plant was removed by weighing the plant sample and then air-drying it. Vegetable samples were dried in oven at $70-80^{\circ} \mathrm{C}$ for $24 \mathrm{hrs}$. to remove moisture from it. Dry vegetable samples were crushed with mortar and pestle and filtered through cotton fabric. All the samples were run in triplicates.

\subsection{Digestion of the Samples}

From different irrigation method three powder samples weighing $0.5 \mathrm{~g}$ was prepared for each leafy vegetables and three replicates were made. Crushing of ash was done with the help of perchloric acid and $\mathrm{HNO}_{3}$ which was in the ratio 1:4. The sample was left to cool down and it was then filtered using What man filtrate paper No 42. A final volume of solution was made with $25 \mathrm{ml}$ of distilled water and was sent for Atomic absorption spectrophotometry.

\subsection{Standards and Statistical Analysis of Data}

Standard solution used (1000 mg/l) (Merck, Germany). Different concentration solution for various metals were also prepared.

Data was compiled in Excel sheet and analyzed statistically by using Statistics' 8.1 (Statistics software). The analysis of the data was achieved by using one-way analysis of variance (ANOVA) and LSD value of $\mathrm{P}<0.05$.

\section{Results and Discussion}

From the following study we can conclude that average concentration ranges from 0.2 to $5.75 \mathrm{mg} / \mathrm{kg}$ for the selected fruits (Table 3 and Figure 3). and vegetables. Iron concentration was higher in all the vegetables and even crossed the permissible limits (Table 2 and Figure 2). Copper concentration were below the safe limits in a water melon and mango. Heavy metals showed their presence could be due to following reasons i.e agricultural practices, geographic position and ability of the plant to absorb heavy metals [5]. Suggested measure may include regular examination of heavy metals in all the food commodities grown in and out. Daily consumption of food results in long term low level body accumulation of heavy metals, with negative impacts only after certain time interval of metal exposure. As a consequence, regular inspection of these heavy metals from different water sources, leafy vegetables and other daily intake is necessary to their entry in our food chain [6].

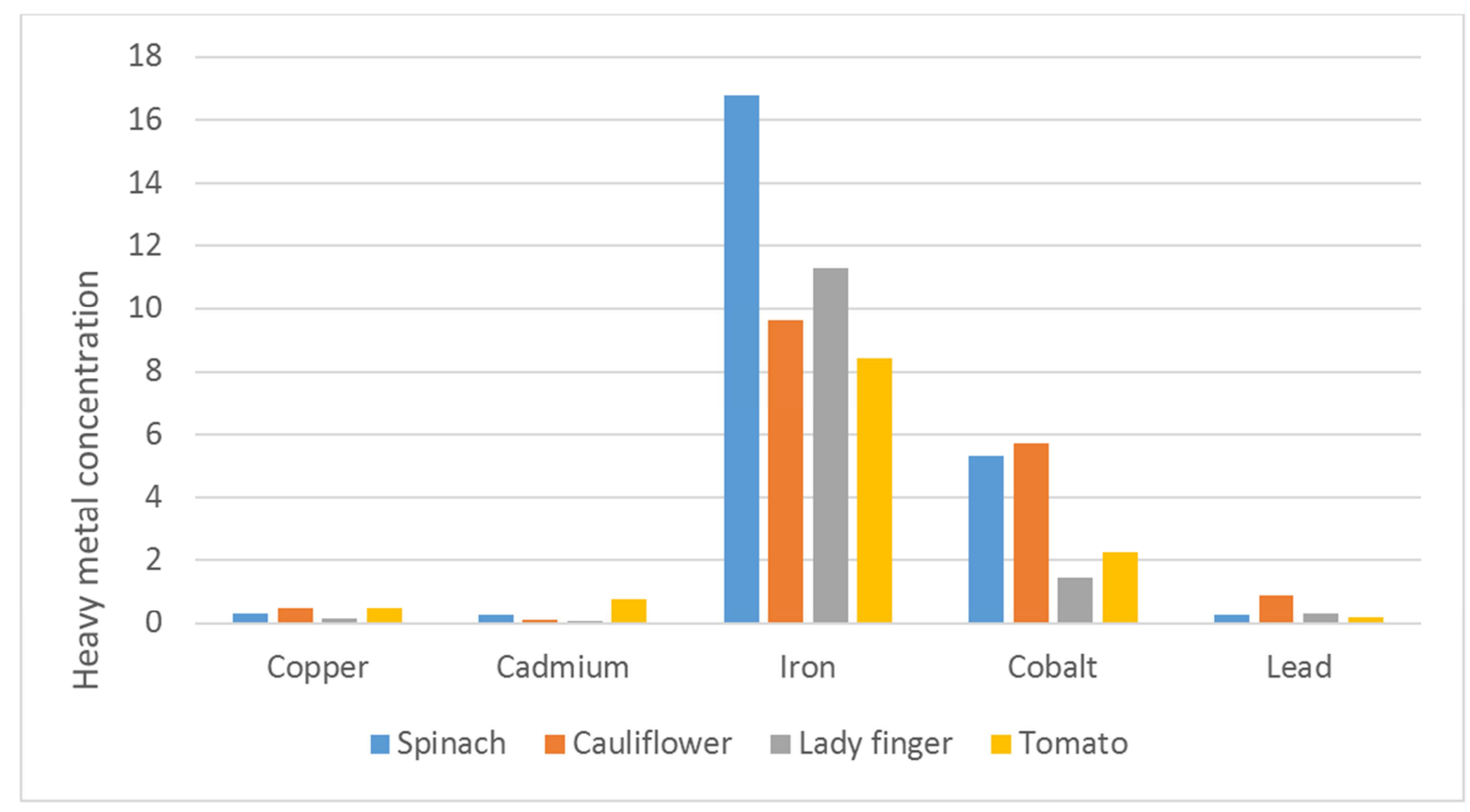

Figure 2. Heavy metals concentration in the selected vegetables. 
Vegetables and Fruits Collected from the Local Market of Prayagraj

Table 2. Heavy metal concentration ( $\mathrm{mg} / \mathrm{kg}$ or ppm) in selected vegetables.

\begin{tabular}{llllll}
\hline Vegetable samples & Copper & Cadmium & Iron & Cobalt & Lead \\
\hline Spinach & 0.31 & 0.26 & 16.81 & 0.25 \\
Cauliflower & 0.5 & 0.1 & 9.64 & 0.91 & 5.74 \\
Lady finger & 0.13 & 0.01 & 11.3 & 1.48 & 0.31 \\
Tomato & 0.511 & 0.78 & 8.426 & 2.243 & 0.2 \\
\hline
\end{tabular}

Table 3. Heavy metal concentration ( $\mathrm{mg} / \mathrm{kg}$ or ppm) in fruits.

\begin{tabular}{llllll}
\hline Fruit sample & Lead & Iron & Zinc & Copper & Cobalt \\
\hline Water melon & 0.52 & 0.04 & 5.10 & 1.18 & 0.142 \\
Mango & 1.814 & 0.352 & 0.625 & 3.185 & 0.511 \\
Guava & 0.2 & 0.05 & 2.33 & 1.4 & 5.142 \\
\hline
\end{tabular}

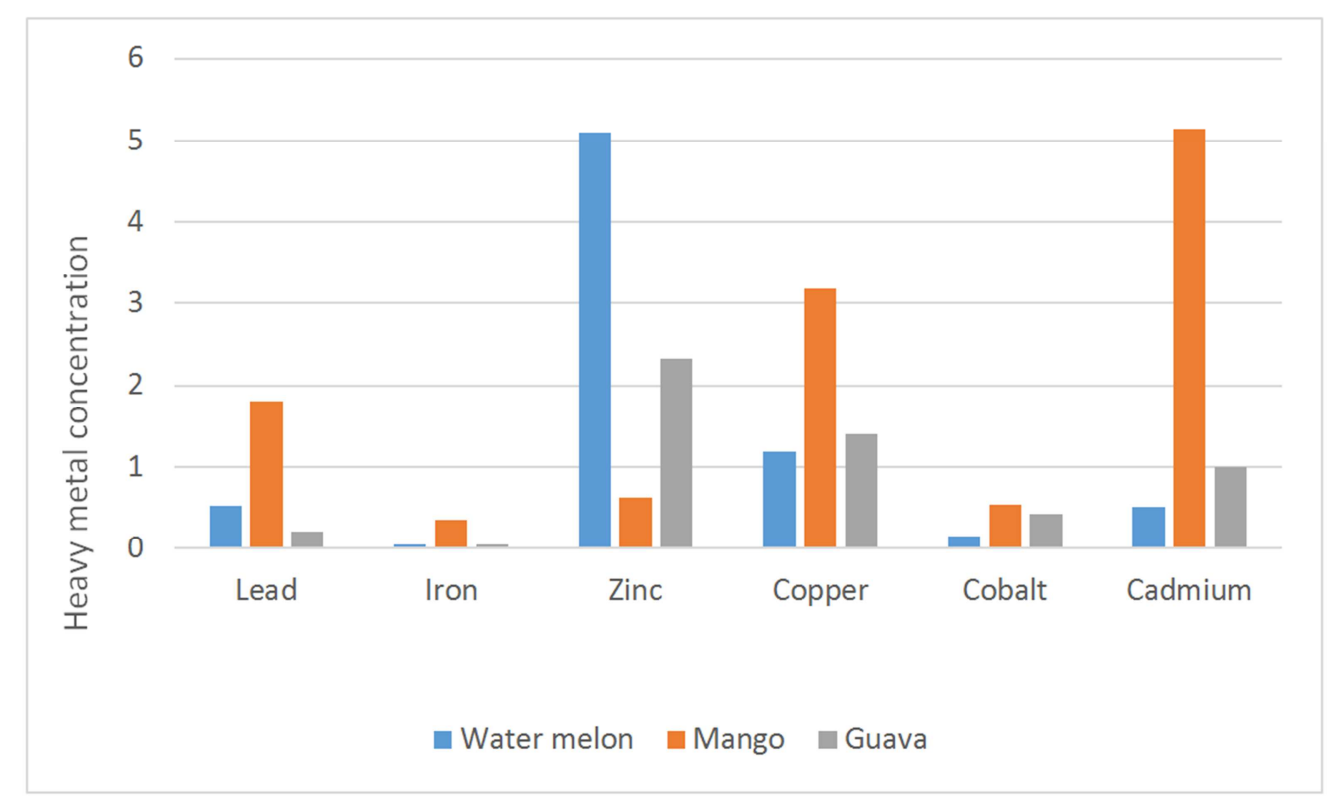

Figure 3. Heavy metal concentration in the selected fruits.

Table 4. Measurement of $\mathrm{pH}$, total soluble solids (TSS), Titratable acidity and Ascorbic acid (mg/kg), moisture and ash contents in fresh, and oven dried vegetables.

\begin{tabular}{|c|c|c|c|c|c|c|}
\hline Treatments & $\mathbf{p H}$ & TSS & Titratable acidity & Ascorbic acid & Moisture content & Ash content \\
\hline Fresh Spinach & $5.00 \mathrm{a}$ & $19.01^{\mathrm{b}}$ & $0.13^{\mathrm{c}}$ & $10.21^{\mathrm{a}}$ & $44.02^{\mathrm{a}}$ & $4.32^{\mathrm{b}}$ \\
\hline Oven dried Spinach & $2.30^{\mathrm{b}}$ & $48.32^{\mathrm{a}}$ & $1.50^{\mathrm{a}}$ & $4.00^{\mathrm{b}}$ & $22.31^{\mathrm{b}}$ & $7.53^{\mathrm{a}}$ \\
\hline Fresh Cauliflower & $5.30 \mathrm{a}$ & $15.00 \mathrm{a}$ & $0.25 \mathrm{c}$ & $9.31 \mathrm{a}$ & $53.11 \mathrm{a}$ & $5.01 \mathrm{a}$ \\
\hline Oven dried Cauliflower & $3.10 \mathrm{~b}$ & $36.01 \mathrm{~b}$ & $2.32 \mathrm{a}$ & $3.12 \mathrm{~b}$ & $6.23 b$ & $12.12 b$ \\
\hline Fresh Lady finger & $4.22 \mathrm{a}$ & $19.32 \mathrm{a}$ & $0.26 \mathrm{a}$ & $13.32 \mathrm{a}$ & $63.31 \mathrm{a}$ & $6.54 \mathrm{a}$ \\
\hline Oven dried Lady finger & $3.44 \mathrm{~b}$ & $58.54 \mathrm{c}$ & $2.52 \mathrm{~b}$ & $7.41 \mathrm{~b}$ & $25.12 b$ & $15.15 b$ \\
\hline Oven dried Tomato & $2.96 \mathrm{~b}$ & $74.02 b$ & $3.13 b$ & $4.41 \mathrm{a}$ & $33.37 b$ & $17.52 b$ \\
\hline
\end{tabular}

Mean values are the results of the triplicate $(\mathrm{n}=3)$. Means with dissimilar alphabets indicate significant difference $(\mathrm{P} \leq 0.05)$, while similar letters indicate nonsignificant difference between treatments.

Table 5. Measurement of pH, total soluble solids (TSS), Titratable acidity and Ascorbic acid (mg/kg), moisture and ash contents in fresh, and oven dried fruits.

\begin{tabular}{|c|c|c|c|c|c|c|}
\hline Treatments & pH & TSS & Titratable acidity & Ascorbic acid & Moisture content & Ash content \\
\hline Fresh Water melon & $6.00^{\mathrm{a}}$ & $22.01^{\mathrm{b}}$ & $0.23^{\mathrm{c}}$ & $12.31^{\mathrm{a}}$ & $92.02^{\mathrm{a}}$ & $3.32^{\mathrm{b}}$ \\
\hline Oven dried Water melon & $3.30^{\mathrm{b}}$ & $58.32^{\mathrm{a}}$ & $1.20^{\mathrm{a}}$ & $5.00^{\mathrm{b}}$ & $30.91^{\mathrm{b}}$ & $6.53^{\mathrm{a}}$ \\
\hline Fresh Mango & $5.00 \mathrm{a}$ & $18.00 \mathrm{a}$ & $0.21 \mathrm{a}$ & $10.31 \mathrm{a}$ & $62.01 \mathrm{a}$ & $4.01 \mathrm{a}$ \\
\hline Oven dried Mango & $2.00 \mathrm{~b}$ & $47.01 \mathrm{c}$ & $1.62 b$ & $4.02 \mathrm{~b}$ & $8.33 c$ & $10.32 b$ \\
\hline Fresh Guava & $5.32 \mathrm{a}$ & $16.32 \mathrm{a}$ & $0.27 \mathrm{a}$ & $14.32 \mathrm{a}$ & $53.41 \mathrm{a}$ & $5.54 \mathrm{a}$ \\
\hline Oven dried Guava & $3.24 b$ & $68.54 \mathrm{~b}$ & $1.92 \mathrm{~b}$ & $6.21 \mathrm{c}$ & $22.32 b$ & $13.45 b$ \\
\hline
\end{tabular}

Mean values are the results of the triplicate $(n=3)$. Means with dissimilar alphabets indicate significant difference $(P \leq 0.05)$, while similar letters indicate nonsignificant difference between treatments. 
The results of physicochemical properties of vegetables and fruits such as $\mathrm{pH}$, Total Soluble Solids (TSS 0Brix), Titratable Acidity, Moisture content, Ascorbic Acid was presented in Table 4 and 5. The results shown in Table 4 showed the $\mathrm{pH}$ values of fresh, and oven dried vegetables Spinach as 5.00, 2.30, Cauliflower 5.30, 3.10, Lady finger 4.22, 3.44 and Tomato 4.83 and 2.96 units. Similarly, Table 5 showed the $\mathrm{pH}$ of fresh and oven dried fruits such as Water melon as 6.00, 3.30, Mango 5.00. 2.00 and Guava 5.32 and 3.24 respectively [7].

These findings illustrate that drying process lowering the hydrogen ion concentration in vegetable and fruits. Our findings are in agreement with that vegetables and fruits contains $\mathrm{pH}$ range from 5.0-5.1 units and the drying process influenced more in lowering $\mathrm{pH}$ content thus decreased. Our findings are further authenticated that vegetables and fruits contain natural $\mathrm{pH}$ which is near to normal $\mathrm{pH}$ [8]. Having normal $\mathrm{pH}$ indicates more suitability of the edible vegetables and fruits when intake does not affect the body $\mathrm{pH}$. Similarly, the total soluble solids (TSS) of fresh and oven dried vegetables and fruits significantly increased in oven dried vegetables and fruits. The highest increase in TSS was observed in oven dried Tomato (74.02) and Guava (68.54) (Tables 4, 5). The increment in TSS concentration of dried vegetables and fruits are due to evaporation of moisture during drying [9]. Our results are closely correlated with the findings that fresh figure contains 22 ( ${ }^{\circ}$ Brix) total soluble solids. However, wild figures are sweeter than other figures because other reported less than 22 (brix) [10].

The present research data revealed that the fresh and oven dried vegetables such as Spinach, Cauliflower, Lady finger and Tomato contains $0.13-1.50 \%, 0.25-2.32 \%, 0.26-2.52 \%$ and $0.19-3.13 \%$ Titratable acidity respectively (Table 4). Similarly, fresh and oven dried Guava Titratable acidity was highest 0.27 and 1.92 as compared with Water melon and Mango (Table 5). The reduction in acidity may be due to catabolic activities in fruit cells and increased in $\mathrm{pH}$ [11].

Ascorbic acid contents in fresh, and oven dried vegetables are presented in Table 4. Results showed that fresh and oven dried Tomato contains highest Ascorbic acid (11.32 and 4.41 $(\mathrm{mg} / \mathrm{kg})$ as compared with other vegetables [12]. Similarly, Table 4 showed highest Ascorbic acid content in Guava $(14.32-6.21 \mathrm{mg} / \mathrm{kg})$ as compared with Water melon and Mango. The results showed massive reductions after oven drying techniques. These results are correspondingly authenticate with other former researchers reported that on drying of vegetables and ascorbic acid concentration degraded because it is highly heat sensitive and may easily degrade vitamin $\mathrm{C}$ content in drying products [13].

The moisture content was also determined as shown in Tables 4 and 5. The moisture content in fresh vegetables such as Spinach, Cauliflower, Lady Finger and Tomato was $44.02 \%, 53.11 \%, 63.31$ and $76.52 \%$ which decreased after oven drying as $22.31 \%, 6.23 \%, 25.12 \%$ and 33.37 respectively (Table 4). Similarly, Table 4 showed moisture content of fresh and oven dried fruits such as Water melon (92.02-30.91\%), Mango (62.01-8.33\%) and Guava (53.41-
22.32\%). These results indicated that moisture content dropped after oven drying. Previous research study also indicated the authenticity of our findings as reported fresh figure contains $75.3 \%$ moisture while dried figures contains $10.43 \%$ respectively [14]. Similar results were also reported by that lowing moisture content below $15 \%$ increases the shelf life of fruits and vegetables products hence drying methods are applied [15].

Ash content of fresh, oven dried vegetables Spinach, Cauliflower, Lady Finger, and Tomato was by about 4.32$7.53 \%, \quad 5.01-12.12 \%, \quad 6.54-15.15 \%$ and $3.51-17.52$ respectively (Table 3 ). Similarly, the ash content in fresh and oven dried fruits such as Water melon, Mango and Guava was $3.32-6.53 \%, 4.01-10.32 \%$ and $5.54-13.45 \%$ respectively (Table 4). Present results indicated that ash content increased after oven drying. Present results are correlated with the findings of that reported that fresh fruits contain lower ash content than dried fruits.

\section{Conclusion}

When any form of wastewater is added to the soil it changes the physical and chemical properties of the soil. We all know that heavy metals intake by the vegetables and fruits are not only affecting the soil profile but also causing serious health issues. In the following study heavy metal accumulation in edible parts of the vegetable were studied showing the presence of heavy metals i.e iron, copper, cadmium, cobalt, lead and zinc. Heavy metals showed their presence could be due to following reasons i.e agricultural practices, geographic position and ability of the plant to absorb heavy metals.

The $\mathrm{pH}$ value of vegetables and fruits dropped after oven drying. Similarly, ascorbic concentration and moisture content significantly decreased after oven drying as compared to fresh vegetables and fruits. However, the Total Soluble solids (TSS) and ash content significantly increased after oven drying as compared with fresh vegetables and fruits.

Suggested measure may include regular examination of heavy metals in all the food commodities grown in and out. Daily consumption of food results in long term low level body accumulation of heavy metals, with negative impacts only after certain time interval of metal exposure.. As a consequence, regular inspection of these heavy metals from different water sources, vegetables and other daily intake is necessary to their entry in our food chain.

\section{Conflict of Interest}

All the authors do not have any possible conflicts of interest.

\section{Acknowledgements}

The authors are grateful to Dr. Ram Bharose Assistant Professor, Sam Higgin bottom University of Agriculture 
Technology and Sciences, Prayagraj, Uttar Pradesh 211007, India for facilitating the necessary support to carry out the current study.

\section{References}

[1] Zhou R, Yu X, Kjær KH, et al (2015) Screening and validation of tomato genotypes under heat stress using $\mathrm{Fv} / \mathrm{Fm}$ to reveal the physiological mechanism of heat tolerance. Environ Exp Bot 118: 1-11. https://doi.org/10.1016/j.envexpbot.2015.05.006.

[2] Arisi ACM, Cornic G, Jouanin L, Foyer CH (1998) Overexpression of iron superoxide dismutase in transformed poplar modifies the regulation of photosynthesis at low $\mathrm{CO} 2$ partial pressures or following exposure to the prooxidant herbicide methyl viologen. Plant Physiol 117: 565-574. https://doi.org/10.1104/pp.117.2.565.

[3] Chazen O, Hartung W, Neumann Pm (1995) The different effects of PEG 6000 and $\mathrm{NaCI}$ on leaf development are associated with differential inhibition of root water transport. Plant, Cell Environ 18: 727-735. https://doi.org/10.1111/j.1365-3040.1995.tb00575.x.

[4] Khan S, Cao Q, Zheng YM, et al (2008) Health risks of heavy metals in contaminated soils and food crops irrigated with wastewater in Beijing, China. Environ Pollut 152: 686-692. https://doi.org/10.1016/j.envpol.2007.06.056.

[5] Xu HL, Wang R, Xu RY, et al (2003) Yield and quality of leafy vegetables grown with organic fertilizations. In: Acta Horticulturae. International Society for Horticultural Science, pp 25-33.

[6] Arasaretnam S, Kiruthika A, Mahendran T (2018) Nutritional and mineral composition of selected green leafy vegetables. Ceylon J Sci 47: 35. https://doi.org/10.4038/cjs.v47i1.7484.

[7] Ori L, Ansari A, Ramnarain YI, Ansari AA (2018) Effect of the use of vermicompost on the plant growth parameters of pak choi (Brassica rapa var. chinensis) and on the soil structure in suriname mushrooms view project earthworms view project effect of the use of vermicompost on the plant growth parameters of pak choi (brassica rapa var. chinensis) and on the soil structure in suriname. Orig Res Artic J Glob Agric Ecol 8: 8-15.

[8] Zakir Iimsziaa (2009) Comparison of heavy and trace metals levels in soil of Peshawar basin at different time intervals. J Chem Soc Pakistan 31: 246-256.

[9] MH Zia (2016) Health risk assessment of potentially harmful elements and dietary minerals from vegetables irrigated with untreated wastewater. Pakistan Environ Geochemistry Heal.

[10] Sorando R, Comín FA, Jiménez JJ, et al (2019) Water resources and nitrate discharges in relation to agricultural land uses in an intensively irrigated watershed. Sci Total Environ 659:

1293-1306.

https://doi.org/10.1016/j.scitotenv.2018.12.023.

[11] Adimalla N, Li P (2019) Occurrence, health risks, and geochemical mechanisms of fluoride and nitrate in groundwater of the rock-dominant semi-arid region, Telangana State, India. Hum Ecol Risk Assess 25: 81-103. https://doi.org/10.1080/10807039.2018.1480353.

[12] Subba Rao N, Chaudhary M (2019) Hydrogeochemical processes regulating the spatial distribution of groundwater contamination, using pollution index of groundwater (PIG) and hierarchical cluster analysis (HCA): A case study. Groundw Sustain Dev 9: 100238. https://doi.org/10.1016/j.gsd.2019.100238.

[13] Chen J, Zhang Y, Chen Z, Nie Z (2015) Improving assessment of groundwater sustainability with analytic hierarchy process and information entropy method: a case study of the Hohhot Plain, China. Environ Earth Sci 73: 2353-2363. https://doi.org/10.1007/s12665-014-3583-0.

[14] Bhattacharya P, Samal AC, Majumdar J, Santra SC (2010) Arsenic contamination in rice, wheat, pulses, and vegetables: A study in an arsenic affected area of West Bengal, India. Water Air Soil Pollut 213: 3-13. https://doi.org/10.1007/s11270-010-0361-9.

[15] Yang T, Kim HJ (2019) Nutrient management regime affects water quality, crop growth, and nitrogen use efficiency of aquaponic systems. Sci Hortic (Amsterdam) 256: 108619. https://doi.org/10.1016/j.scienta.2019.108619. 